\title{
Kajian Karakteristik Pasang Surut Di Perairan Teluk Balikpapan Menggunakan Metode Admiralty
}

\author{
Alvina Resha Octaferina \\ Teknologi Geomatika, Politeknik Pertanian Negeri \\ Samarinda, Samarinda, 75131 \\ alvinaresha13@gmail.com
}

\author{
F. V. Astrolabe Sian Prasetya* \\ Teknologi Geomatika, Politeknik Pertanian Negeri \\ Samarinda, Samarinda, 75131 \\ astrolabesp@politanisamarinda.ac.id \\ *Corresponding author
}

\begin{abstract}
Abstrak-Banyaknya kegiatan di Perairan Teluk Balikpapan sehingga diperlukan pengamatan pasang surut untuk mengetahui karakterisik dan tipe pasang surut. Karakteristik dan tipe pasang surut memiliki manfaat untuk memberikan gambaran umum tentang berapa kali pasang atau surut, tanggal LLWL dan HHWL serat fase bulannya, sehingga dapat memberikan acuan yang diperlukan untuk melaksanakan kegiatan di Perairan Teluk Balikpapan. Tujuan dari kajian ini adalah untuk mengetahui karakteristik dan grafik pasang surut di Perairan Teluk Balikpapan. Data yang digunakan merupakan data pasang surut bulan November tahun 2019 dari Stasiun Pengamatan Pasang Surut yang berlokasi di Pelabuhan Semayang, Teluk Balikpapan. Metode yang digunakan adalah metode perhitungan Admiralty dan Formzahl.

Hasil dari penelitian ini berupa 2 (dua) nilai konstituen komponen harmonic pasang surut dari perhitungan metode Admiralty yaitu nilai amplitudo (A) dan sudut fase $\left(\mathrm{g}^{\circ}\right)$, nilai Formzahl, nilai $M S L$, $H H W L$ dan $L L W L$ dari perhitungan metode Admiralty, nilai $H H W L$ dan $L L W L$ dari analisa data pasang surut serta fase bulan dan grafik pasang surut. Karakteristik pasang surut di Perairan Teluk Balikpapan pada bulan November didominasi oleh gaya pembangkit pasang surut dari matahari (S) dengan nilai amplitudo (A) sebesar 67,990 $\mathrm{cm}$. Tipe pasang surut di Perairan Teluk Balikpapan adalah mixed, prevailling semidiurnal (campuran, condong ke harian ganda) dengan nilai Formzahl sebesar 0,33. Nilai $M S L$ dari perhitungan Admiralty sebesar 1,42 $\mathrm{m}$, nilai $H H W L$ sebesar $3,30 \mathrm{~m}$ dan nilai $L L W L$ sebesar 0,31 m. Pada tanggal 14 November 2019, nilai $H H W L$ sebesar 2,90 m dan nilai $L L W L$ sebesar $0,20 \mathrm{~m}$. Pada tanggal 28 November 2019, nilai $H H W L$ sebesar 2,80 m dan $L L W L$ sebesar $0,20 \mathrm{~m}$. Fase bulan pada tanggal 14 yaitu Waning Gibbous 94\% dan pada tanggal 28 yaitu Waxing Crescent 5\%.
\end{abstract}

Kata Kunci-Pasang Surut, Karakteristik, Admiralty, Formzahl

\section{PENDAHULUAN}

Indonesia merupakan salah satu negara kepulauan yang berada di Asia Tenggara, yang memiliki kondisi dan karakter geografis perairan yang sangat luas. Hal tersebut ditandai dengan banyaknya pulau, panjang garis pantai dan perairannya (Syetiawan, 2014). Fakta ini tentu menjadi acuan untuk pembangunan di sektor kelautan dan pesisir sehingga perlunya penerapan survei hidrografi dalam mewujudkan pembangunan nasional Indonesia. Salah satu dari penerapan survei hidrografi adalah pengamatan pasang surut air laut, yang datanya sangat diperlukan untuk penentuan jalur transportasi laut (navigasi), kegiatan pembangunan di pelabuhan dan wilayah pesisir pantai maupun lepas pantai karena mengingat wilayah Indonesia yang berupa negara kepulauan (Jayanti, 2016).

Fenomena pasang surut merupakan suatu kejadian alam yang berupa proses naik dan turunnya permukaan air laut secara periodik. Fenomena ini ditimbulkan oleh gaya tarik menarik (gravitasi) antara benda-benda langit yang ada di angkasa. Gaya gravitasi yang paling besar adalah dari matahari dan bulan terhadap air laut di permukaan bumi (Zakaria, 2015). Pasang surut dinyatakan dengan "pasut" yang merupakan gerak naik dan turun muka air laut dengan periode rata-rata sekita 12,4 jam atau 24,8 jam. Data pasang surut dapat digunakan sebagai acuan bidang referensi untuk mengetahui kedalam suatu titik di dasar perairan dan ketinggian titik di pantai, peramalan pasang surut di suatu tempat, karakteristik pasang surut dan fenomena yang mempengaruhi tinggi muka air laut. Oleh karena itu, pergerakan gelombang pasang surut laut dapat dimodelkan menjadi grafik amplitudo pasang surut (Poerbandono, 2005).

Perairan Teluk Balikpapan merupakan salah satu perairan yang terletak di Provinsi Kalimantan Timur. Secara geografis, Perairan Teluk Balikpapan berada di

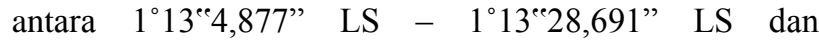

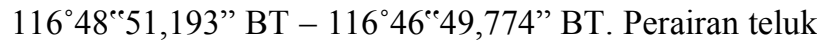
ini merupakan jalur penghubung antara kota-kota di dalam dan luar Kalimantan Timur sebagai jalur mobilitas orang dan barang hasil produksi (ekspor dan impor) serta kegiatan pembangunan industri, pertambangan, perkebunan, pertanian dan kehutanan (Sulardi, 2016). 
Dalam menjalankan aktivitas di sekitar wilayah perairan, pengetahuan tentang karakteristik dan tipe pasang surut dapat memberikan gambaran umum tentang berapa kali pasang atau surut, tanggal $L L W L$ dan $H H W L$ serta fase bulannya, sehingga dapat memberikan acuan yang diperlukan untuk melaksanakan kegiatan di Perairan Teluk Balikpapan.

\section{STUDI PUSTAKA}

Pada kajian ini, dilakukan studi pustaka dari sumber penelitian terdahulu yang pernah dilakukan pada lokasi yang sama, ataupun pada lokasi yang berbeda dengan megnggunakan metode yang sama dengan metode pada kajian ini, adalah sebagai berikut:

1. Menurut Hidayat (2016), data pasang surut yang digunakan adalah data dari Stasiun Pasang Surut Teluk Balikpapan bulan April 2015. Metode perhitungan pasang surut yang digunakan adalah Admiralty dan Formzahl. Hasil dari penelitian ini berupa nilai amplitudo (A) dan sudut $\left(\mathrm{g}^{\circ}\right)$ Komponen Harmonik Pasang Surut dan tipe pasang surut Perairan Teluk Balikpapan.

2. Menurut Siagian (2016), data pasang surut yang digunakan adalah data pengamatan selama 15 hari dengan interval 1 jam. Metode perhitungan pasang surut yang digunakan adalah Admiralty dan Formzahl. Hasil dari perhitungan ini berupa nilai amplitudo (A) dan sudut $\left(\mathrm{g}^{\circ}\right)$ Komponen Harmonik Pasang Surut, tipe dan grafik pasang surut Perairan Teluk Balikpapan.

3. Menurut Sulardi (2016), data pasang surut yang digunakan adalah data pengamatan selama 15 hari menggunakan alat Moritide dengan interval 1 jam. Metode perhitungan pasang surut yang digunakan adalah Admiralty dan Formzahl. Hasil dari penelitian ini berupa nilai amplitudo (A) dan sudut $\left(\mathrm{g}^{\circ}\right)$ Komponen Harmonik Pasang Surut, tipe dan grafik pasang surut Perairan Teluk Balikpapan.

4. Menurut Khomsin (2013), pada penelitian yang berjudul "Perbandingan Akurasi Prediksi Pasang Surut antara Metode Admiralty dan Metode Least Square", data pasang surut yang digunakan adalah data pasang surut Stasiun Surabaya selama 29 hari. Metode yang digunakan adalah metode Admiralty dan Least Square. Hasil dari penelitian ini adalah berupa nilai amplitudo $(\mathrm{A})$ dan sudut $\left(\mathrm{g}^{\circ}\right)$ serta selisihnya dan nilai $R M S E$.

5. Menurut Jayanti (2016), dimana penelitiannya dilakukan pada perairan di Pelabuhan Kuala Tanjung, data pasang surut yang digunakan adalah data sekunder dari bulan Januari s/d Desember 2016. Metode perhitungan yang digunakan adalah metode Admiralty dan Least Square. Hasil dari penelitian ini berupa nilai amplitudo (A) dan sudut $\left(\mathrm{g}^{\circ}\right)$ serta selisihnya.

6. Menurut Zakaria (2015), dimana penelitiannya dilakuka pada perairan di Pelabuhan Panjang, Teluk Betung, Provinsi Bengkulu, data pasang surut yang digunakan adalah data pasang surut Stasiun Pelabuhan Panjang dari bulan Januari 2002 s/d 2004. Metode perhitungan yang digunakan adalah metode Least Square dan Fast Fourier Transform. Hasil dari penelitian ini berupa grafik perbandingan data pengamatan dengan model periodik hasil dari 2 (dua) metode yang digunakan.

7. Menurut Ichsari (2020), dimana penelitiannya dilakukan pada perairan di Pelabuhan Malahayanti, data pasang surut yang digunakan adalah data pengamatan langsung dari 1 Januari 2013 s/d 31 Desember 2018. Metode perhitungan yang digunakan adalah metode Admiralty, Least Square dan Fast Fourier Transform. Hasil dari penelitian ini berupa nilai amplitudo $(\mathrm{A})$ dan sudut $\left(\mathrm{g}^{\circ}\right)$ serta selisihnya dan tipe pasang surut.

\section{METODOLOGI}

Daerah kajian penentuan karakteristik pasang surut ini berada pada Stasiun Pengamatan Pasang Surut Balikpapan, Pelabuhan Semayang, Teluk Balikpapan.

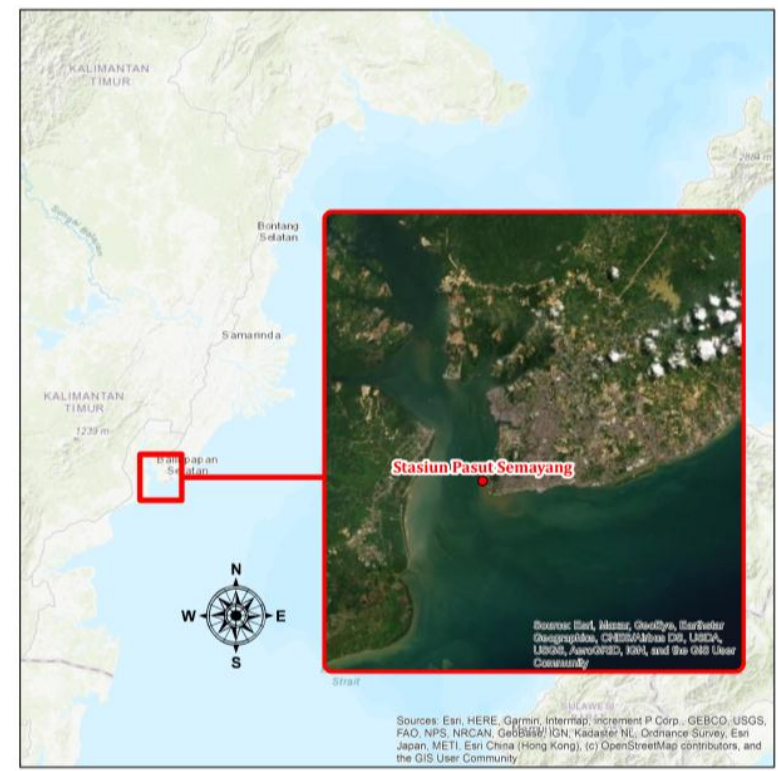

Gambar1. Lokasi Kajian Pasang Surut

Pada kajian ini digunakan data Pasang Surut Perairan Teluk Balikpapan pada rentang waktu 1 bulan terhitung dari tanggal 1 s/d 29 November 2019, dimana data tersebut bersumber dari Pushidrosal Balikpapan, Kalimantan Timur.

\section{$\underline{\text { Pengolaha data }}$}

Pengolahan data penelitian ini menggunakan software Microsoft Excel 2016. Tahapan pengolahan data penelitian ini meliputi penyusunan data pada skema, penjumlahan dan pengurangan data skema, pengalian data skema dengan konstanta pengali, perhitungan Formzahl, analisa data untuk mencari nilai $H H W L$ dan $L L W L$ dan analisa fase bulan. Berikut bagan alir perhitungan data disajikan pada Gambar 2. 


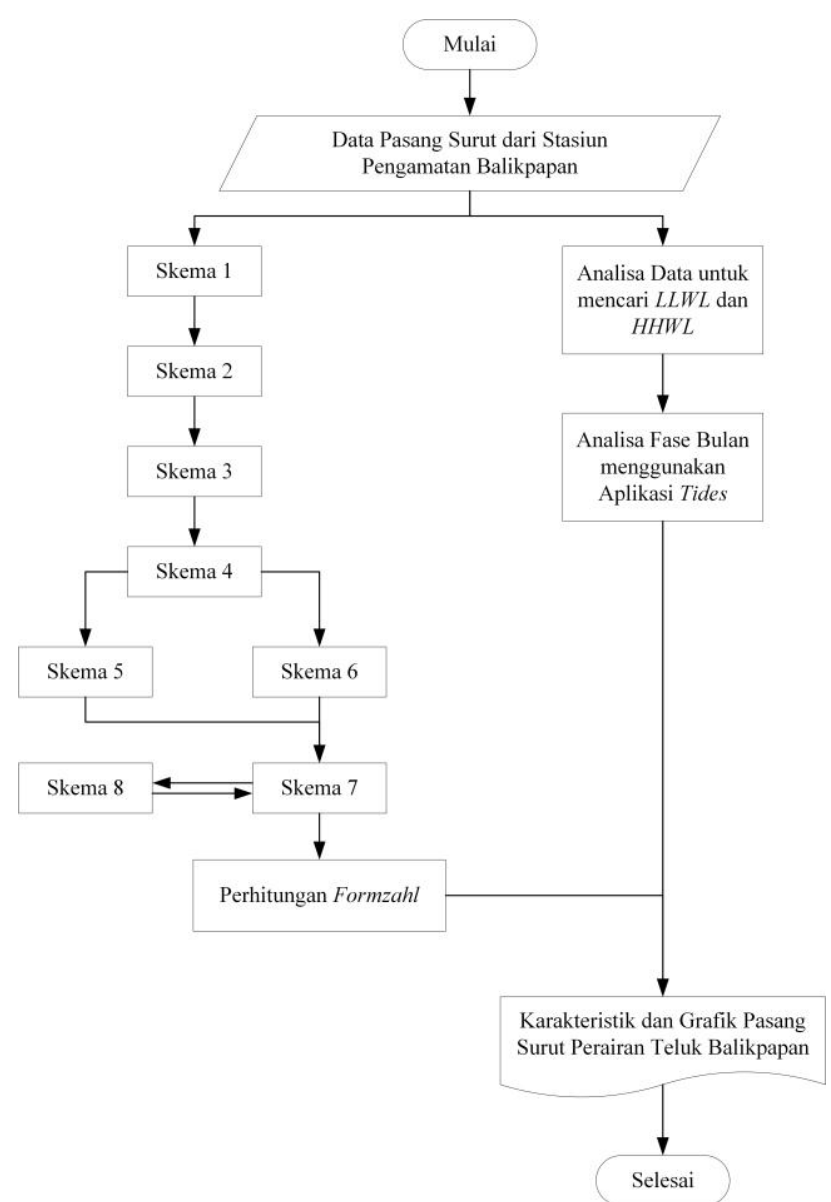

Gambar 2. Tahapan Pengolahan Data Pasang Surut

$\underline{\text { Skema } 1}$

Menyusun data muka air menurut Skema 1 dengan satuan centimeter (Tabel 7). Kolom Skema 1 menunjukkan waktu pengamatan dari pukul 00.00 sampai 23.00, dan ke bawah menunjukkan tanggal selama 29 hari (29 piantan), yaitu tanggal 1 s/d 29 November tahun 2019.

Skema 2

Skema 2 (Tabel 9) diisi dengan mengalikan data pasang surut pada Skema 1 dengan Konstanta Pengali Skema 2 (Tabel 8) pada masing-masing hari pengamatan. Tabel 6 berisi deretan bilangan 1 dan -1, kecuali untuk X4 pada bilangan 0 tidak dimasukkan dalam perkalian. Kemudian, perhitungan dilakukan dengan menjumlahkan bilangan yang dikalikan dengan 1 dan diisi di bawah kolom bertanda (+) pada Skema 2 . Hal yang sama juga dilakukan untuk penjumlahan dari perkalian dengan bilangan -1 .

Skema 3

Skema 3 (Tabel 10) diisi dengan penjumlahan Skema 2 menurut tanda minus (-) dan plus (+). Berikut prosedur kerja pengisian Skema 3:

a. Pada kolom X0 (+) diisi dengan menjumlahkan X1 (), tanpa melihat tanda.

b. Pada kolom X1, Y1, X2, Y2, X4 dan Y4 diisi dengan menjumlahkan masing-masing tanda (+) dan (-). Agar hasil tidak negatif, setiap hasil penjumlahan pada $\mathrm{X} 1$, Y1, X2 dan Y2 ditambahkan dengan 2000 dan pada hasil penjumlahan $\mathrm{X} 4$ dan $\mathrm{Y} 4$ ditambahkan dengan 1000.

$\underline{\text { Skema } 4}$

Pengisian kolom-kolom pada Skema 4 (Tabel 12) dibantu dengan Konstanta Pengali Skema 4 (Tabel 11). Nilai X00 yang diisi pada kolom X merupakan penjumlahan dari nilai X0 dari Skema 3 yang telah dikalikan dengan faktor pengali dari Konstanta Pengali Skema 4 kolom 0, di mana perkalian dilakukan per baris. $\underline{\text { Skema } 5 \text { dan } 6}$

Skema 5 dan 6 diisi dengan bantuan Konstanta Pengali Skema 5 dan 6 (Tabel 13). Kolom pertama dan kedua diisi sesuai hasil pengurangan (untuk Skema 5) dan penjumlahan (untuk Skema 6) pada Skema 4 (Tabel 12) di kolom X00, X10 dan Y10. Kemudian, dikalikan dengan Konstanta Pengali Skema 5 dan 6.

Skema 7

Skema 7 (Tabel 15) memiliki 15 baris yang akan diisi dengan beberapa formula. Kolom-kolom pada Skema 7 merupakan penjumlahan dari Skema 5 dan Skema 6 dan dibantu dengan Konstanta Pengali Dealer $\mathrm{P}$ dan Konstanta p (Tabel 14) serta data hasil perhitungan $\mathrm{f}$, $\mathrm{V}$, u dan $\mathrm{r}$.

$\underline{\text { Skema } 8}$

Pada Skema 8 (Tabel 16) dilakukan perhitungan baris ke-6 Nilai $1+\mathrm{W}$ dan baris ke-9 Nilai w pada Skema 7 (Tabel 14) dan perhitungan dari nilai V dan nilai u pada Skema 7 dibantu dengan konstanta pengali yang telah ditetapkan dan hasil perhitungan $\mathrm{f}, \mathrm{V}$, u dan $\mathrm{r}$.

\section{HASIL DAN PEMBAHASAN}

Berdasarkan dari Kajian Karakteristik Pasang Surut di Perairan Teluk Balikpapan menggunakan Metode Admiralty dengan data pasang surut tanggal 1 s/d 29 November tahun 2019 (29 piantan) dengan interval waktu pengamatan per 1 jam diperoleh hasil pengolahan data Skema 1, Skema 2, Skema 3, Skema 4, Skema 5, Skema 6, Skema 7, Skema 8, nilai amplitudo (A) dan sudut fase $\left(\mathrm{g}^{\circ}\right)$ komponen harmonik pasang surut, nilai $M S L, H H W L$ dan $L L W L$ berdasarkan perhitungan Admiralty dan nilai $H H W L$ dan $L L W L$ berdasarkan analisa data pasang surut, fase bulan serta grafik pasang surut Perairan Teluk Balikpapan bulan November tahun 2019.

1. Hasil Perhitungan Data Pasang Surut menggunakan Metode Admiralty

Pengolahan data pasang surut Perairan Teluk Balikpapan bulan November 2019 menggunakan metode perhitungan Admiralty menghasilkan 8 skema dan nilai amplitudo (A) dan sudut $\left(\mathrm{g}^{\circ}\right)$ komponen harmonik pasang surut.Hasil dari perhitungan metode Admiralty adalah nilai Amplitudo (A) dan sudut fase $\left(\mathrm{g}^{\circ}\right)$ komponen harmonik pasang surut yang terdapat pada Skema 7 baris ke 14 dan 15. Hasil tersebut dapat dilihat pada Tabel 1.

Tabel 1. Hasil Komponen Harmonik Pasut Perairan Teluk Balikpapan

\begin{tabular}{ccccccccccc}
\hline & $\mathrm{S}_{0}$ & $\mathrm{M}_{2}$ & $\mathrm{~S}_{2}$ & $\mathrm{~N}_{2}$ & $\mathrm{~K}_{1}$ & $\mathrm{O}_{1}$ & $\mathrm{M}_{4}$ & $\mathrm{MS}_{4}$ & $\mathrm{~K}_{2}$ & $\mathrm{P}_{1}$ \\
\hline $\begin{array}{c}\mathrm{A} \\
(\mathrm{cm})\end{array}$ & 141,87 & 47,88 & 67,99 & 7,61 & 19,85 & 18,75 & 1,43 & 2,39 & 18,00 & 7,00 \\
$\mathrm{~g}^{\circ}$ & & 197,09 & 181,85 & 30,42 & 317,75 & 232,38 & 155,68 & 7,70 & 197,09 & 181,85 \\
\hline
\end{tabular}




\section{Hasil Perhitungan Formzahl}

Penentuan tipe pasang surut di Perairan Teluk Balikpapan menggunakan nilai amplitudo (A) dari komponen $\mathrm{M}_{2}, \mathrm{~S}_{2}, \mathrm{~K}_{1}$ dan $\mathrm{O}_{1}$. Nilai ini dihitung menggunakan rumus Formzahl. Hasil dari perhitungan ini disajikan pada Tabel 2.

Tabel 2. Hasil Perhitungan Formzahl dan Tipe Pasang Surut Perairan Teluk Balikapapn

\begin{tabular}{|c|c|c|c|}
\hline Amplitudo & $\begin{array}{l}\text { Nilai } \\
(\mathrm{cm})\end{array}$ & $\begin{array}{c}\text { Nilai } \\
\text { Formzahl }\end{array}$ & Tipe Pasang Surut \\
\hline $\mathrm{K}_{1}$ & 19,85 & \multirow[t]{4}{*}{0,33} & \multirow{4}{*}{$\begin{array}{l}\text { Mixed tides, prevailling } \\
\text { semidiurnal } \\
\text { condong ke harian ganda) }\end{array}$} \\
\hline $\mathrm{O}_{1}$ & 18,75 & & \\
\hline $\mathrm{M}_{2}$ & 47,88 & & \\
\hline $\mathrm{S}_{2}$ & 67,99 & & \\
\hline
\end{tabular}

Dari Tabel 2 di atas dapat dilihat bahwa hasil dari perhitungan Formzahl adalah 0,33 yaitu tipe pasang surut di perairan Balikpapan adalah tipe campuran condong ke harian ganda (mixed tides, prevailling semi diurnal).

3. Nilai MSL, HHWL dan $L L W L$ berdasarkan Perhitungan Metode Admiralty

Perhitungan data pasang surut menggunakan metode Admiralty menghasilkan nilai $M S L, H H W L$ dan $L L W L$. Nilai $M S L$ merupakan nilai amplitudo (A) dari komponen S0. Nilai $H H W L$ dan $L L W L$ dihitung dengan rumus yang disajikan beserta nilai $M S L$ pada Tabel 3.

Tabel 3. Nilai $M S L, H H W L$ dan $L L W L$ berdasarkan Perhitungan Admiralty

\begin{tabular}{llc}
\hline \multicolumn{2}{c}{ Datum Vertikal } & Nilai $(\mathrm{m})$ \\
\hline $\mathrm{MSL}$ & $=\mathrm{S}_{0}$ & 1,42 \\
$\mathrm{HHWL}$ & $=\mathrm{S}_{0}+\Sigma \mathrm{A}$ & 3,33 \\
LLWL & $=\mathrm{S}_{0}-\Sigma \mathrm{A}$ & $-0,31$ \\
\hline
\end{tabular}

4. Nilai $H H W L$ dan $L L W L$ berdasarkan Analisa Data Pasang Surut

Analisa data pasang surut menghasilkan nilai $H H W L$ dan $L L W L$ yang dilihat dari jam dan tanggal pengamatan pada bulan November tahun 2019 beserta fase bulannya yang disajikan pada Tabel 4.

Tabel 4. Nilai $H H W L$ dan $L L W L$ berdasarkan Analisa Data Pasang Surut

\begin{tabular}{cccccc}
\hline Tgl/BIn/Thn & Jam & $\begin{array}{c}\text { LLWL } \\
(\mathrm{m})\end{array}$ & Jam & $\begin{array}{c}\text { HHWL } \\
(\mathrm{m})\end{array}$ & Fase Bulan \\
\hline $14 / 11 / 2019$ & 12.00 WITE & 0,20 & 19.00 WITE & 2,90 & Waning Gibbous \\
& & & & & \\
$28 / 11 / 2019$ & 12.00 WITE & 0,20 & 19.00 WITE & 2,80 & $\begin{array}{c}\text { Waxing Crescent } \\
(5 \%)\end{array}$ \\
\hline
\end{tabular}

Berdasarkan hasil yang diperoleh dari perhitungan data pasang surut Perairan Teluk Balikpapan menggunakan metode Admiralty dan analisa data pasang surut, diperoleh nilai amplitudo (A) dan sudut fase $\left(\mathrm{g}^{\circ}\right)$ komponen harmonik pasang surut dari perhitungan data pasang surut menggunakan 8 skema, konstanta pengali dan formula yang akan digunakan untuk menentukan karakteristik pasang surut di Perairan Teluk Balikpapan. Pada analisa data pasang surut, didapatkan hasil berupa nilai $H H W L$ dan $L L W L$ berdasarkan tanggal dan jam pengamatan pada bulan November 2019.

1. Karakteristik Pasang Surut Perairan Teluk Balikpapan

Karakteristik pasang surut ditentukan dari besarnya nilai amplitudo (A) dari komponen $\mathrm{M}_{2}$ dan $\mathrm{S}_{2}$ yang juga nilai ini akan digunakan pada perhitungan bilangan Formzahl untuk menentukan tipe pasang surut.

a. Gaya Pembangkit Pasang Surut

Dari hasil nilai amplitudo pada komponen $\mathbf{M}_{2}$ dan $\mathrm{S}_{2}$ (Tabel 1) pengaruh gaya pembangkit pasut dari bulan $\left(\mathrm{M}_{2}\right)$ pengaruh gaya pembangkit pasut dari matahari $\left(\mathrm{S}_{2}\right)$ dengan nilai amplitude $\mathbf{M}_{2}$ sebesar $47.88 \mathrm{~cm}$ dan nilai amplitudo $\mathrm{S}_{2}$ sebesar $67,99 \mathrm{~cm}$. Sehingga pasang surut di Perairan Teluk Balikpapan didominasi oleh gaya pembangkit pasang surut dari matahari. Tinggi dari amplitudo $\mathrm{S}_{2}\left(\mathrm{AS}_{2}\right)$ dan $\mathrm{M}_{2}$ $\left(\mathrm{AM}_{2}\right)$ ditarik dari garis $M S L$ daapt dilihat pada Gambar 3.

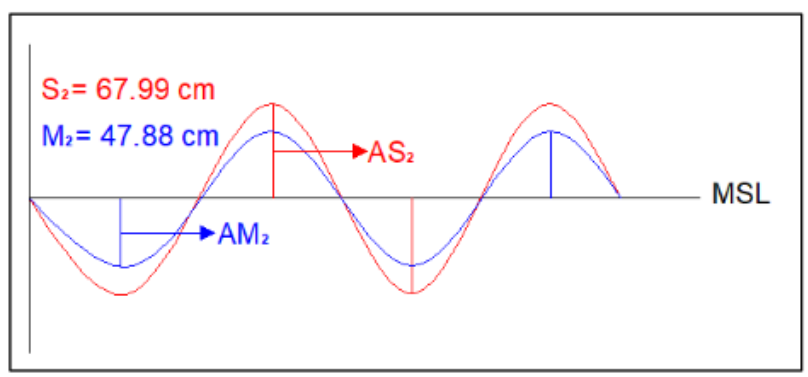

Gambar 3. Tinggi Amplitudo Komponen $\mathrm{S}_{2}$ dan $\mathrm{M}_{2}$

Gaya pembangkit ini sesuai dengan penjelasan Doodson (1928) bahwa $\mathrm{M}_{2}$ dan $\mathrm{S}_{2}$, saling terkait satu sama lain dalam pasang surut. Sehingga nilai amplitudonya $\mathrm{M}_{2}$ lebih besar daripada nilai $\mathrm{S}_{2}$. Namun, secara alami, nilai amplitudo ini dapat bervariasi dan dalam keadaan khusus, mungkin lebih besar nilai $\mathrm{S}_{2}$ daripada $\mathrm{M}_{2}$. Seperti pasang surut pada bulan November 2019 di Perairan Teluk Balikpapan, yang menghasilkan nilai $S_{2}$ lebih besar daripada nilai $\mathrm{M}_{2}$ dikarenakan posisi bumi saat berevolusi berada hampir mendekati matahari pada Gambar 10.

b. Tipe Pasang Surut

Tipe pasang surut ditentukan menggunakan perhitungan Formzahl dengan menggunakan amplitudo dari komponen harmonik bulan $\left(\mathrm{M}_{2}\right)$, matahari $\left(\mathrm{S}_{2}\right)$, deklinasi bulan dan matahari $\left(\mathrm{K}_{1}\right)$ dan deklinasi matahari $\left(\mathrm{P}_{1}\right)$.

Berdasarkan hasil perhitungan bilangan Formzahl pada Tabel 26, dapat diketahui bahwa hasil tipe pasang surut perairan Balikpapan adalah tipe pasang surut campuran, condong ke harian ganda (mixed, prevailing semidiurnal tide) dengan nilai $\mathrm{F}$ sebesar 0,33 , sesuai dengan klasifikasi pasang surut, condong ke harian ganda adalah $0,25 \leq \mathrm{F} \leq 1,5$ (Tabel $\mathrm{xx}$ ). Tipe ini adalah tipe pasang surut yang terjadi dua kali pasang dan dua kali surut dalam 1 piantan, namun kadang terjadi 1 kali pasang atau 1 kali surut. Hasil dari tipe pasang surut Perairan Teluk Balikpapan ini sejalan dengan hasil penelitian dari Sinaga (2013), 
Sulardi (2016), Siagian (2016) dan Hidayat (2016), yang menyatakan bahwa tipe pasang surut di Perairan Teluk Balikpapan adalah tipe campuran condong ke harian ganda.

\section{Grafik Pasang Surut Perairan Teluk Balikpapan}

Grafik pasang surut Perairan Teluk Balikpapan merupakan hasil dari pasang surut pada bulan November tahun 2019. Pada grafik ini, terdapat nilai $M S L, H H W L$ dan $L L W L$ dari perhitungan metode Admiralty serta nilai $H H W L$ dan $L L W L$ berdasarkan analisa data pasang surut selama 29 hari.

a. Nilai $M S L, H H W L$ dan $L L W L$ berdasarkan hasil perhitungan Admiralty

Berdasarkan hasil pada Tabel xx, nilai $M S L$ didapat dari perhitungan Admiralty yaitu nilai amplitudo $\mathrm{S}_{0}$ sebesar 1,42 m. Nilai $H H W L$ didapat dari menjumlahkan nilai $\mathrm{S}_{0}$ dengan $\mathrm{Z}_{0}$ sebesar $3,33 \mathrm{~m}$. Nilai $L L W L$ didapat dari mengurangkan nilai $S_{0}$ dengan $\mathrm{Z}_{0}$ sebesar $-0,31 \mathrm{~m}$. $\mathrm{Z}_{0}$ adalah muka surutan air yang dihitung dengan mengurangkan nilai $M S L$ $\left(\mathrm{S}_{0}\right)$ dengan sigma seluruh nilai amplitudo kecuali $\mathrm{S}_{0}$. Berikut tinggi nilai $M S L, H H W L$ dan $L L W L$ dapat dilihat pada Gambar 4.

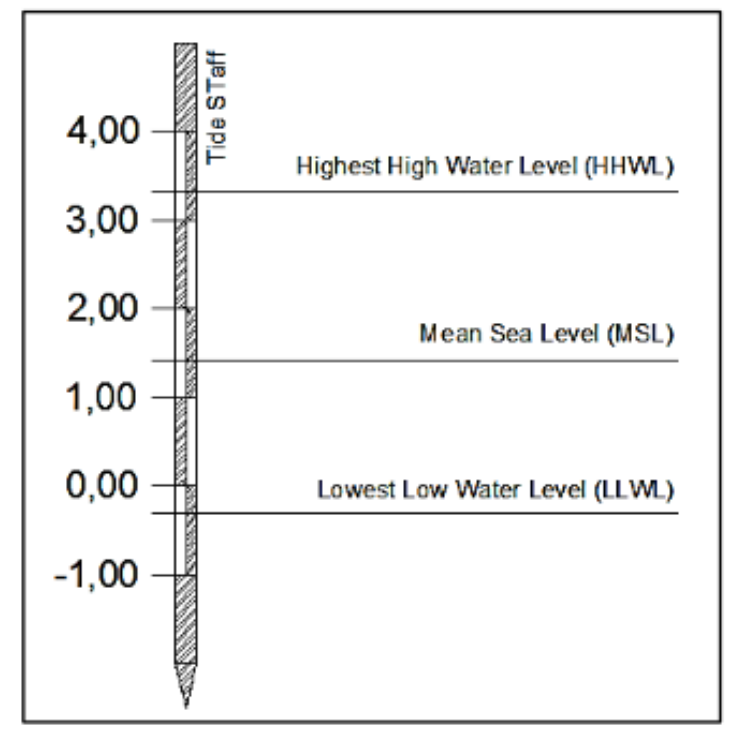

Gambar 4. Skema nilai $M S L, H H W L$ dan $L L W L$

b. Nilai $H H W L$ dan $L L W L$ berdasarkan Analisa Data Pasang Surut Perairan Teluk Balikpapan

Berdasarkan hasil pada Tabel 28, HHWL dan LLWL terjadi 2 (dua) kali dalam 1 bulan yaitu pada tanggal 14 November 2019 dan 28 November 2019. Pada tanggal 14 November 2019, nilai $H H W L$ sebesar 2,90 $\mathrm{m}$ dan nilai $L L W L$ sebesar $0,20 \mathrm{~m}$. pada tanggal 28 November 2019, nilai $H H W L$ sebesar 2,80 m dan nilai $L L W L$ sebesar $0,20 \mathrm{~m}$.

$H H W L$ dan $L L W L$ dapat dilihat pada grafik pasang surut Perairan Teluk Balikpapan bulan November tahun 2019 pada Gambar 5, 6, 7 dan 8. Tinggi $H H W L$ dan $L L W L$ pada tanggal 14 dapat dilhat pada Gambar 5 dan 6. Tinggi $H H W L$ dan $L L W L$ pada tanggal 28 dapat dilihat pada Gambar 7 dan 8.

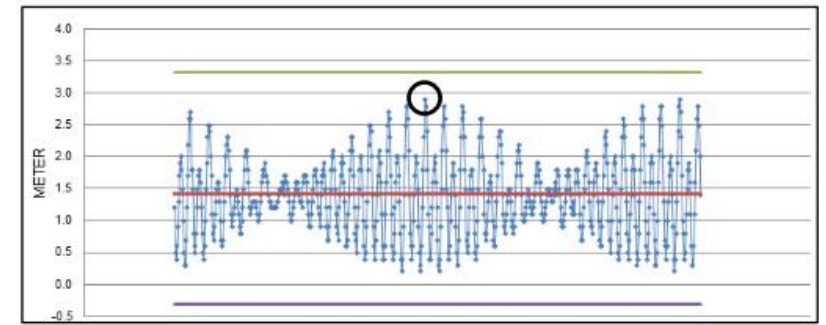

Gambar 5. HHWL pada tanggal 14 November 2019

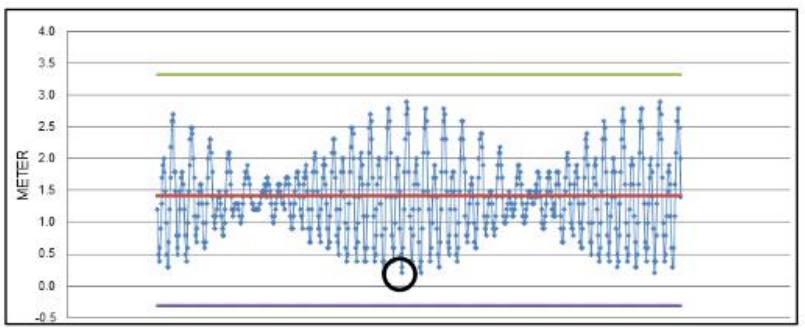

Gambar 6. LLWL pada tanggal 14 November 2019

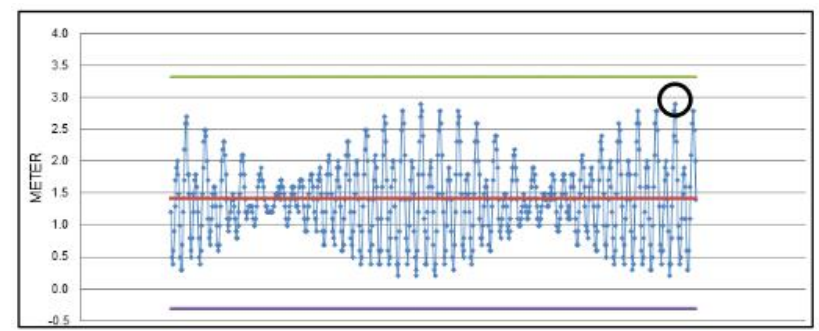

Gambar 7. HHWL pada tanggal 28 November 2019

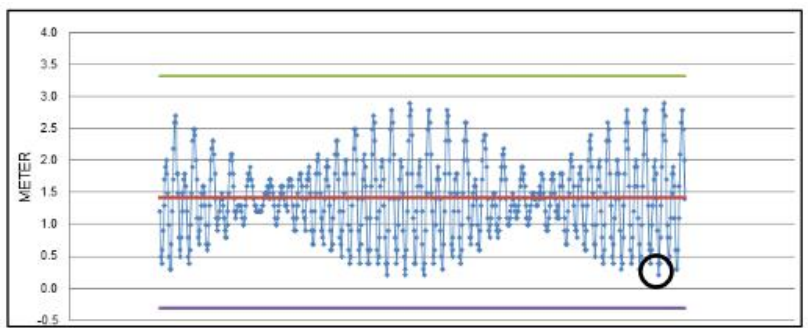

Gambar 8. LLWL pada tanggal 28 November 2019

Keterangan garis pada Gambar 5, 6, 7 dan 8:

Garis Hijau : Highest High Water Level (HHWL)

Garis Merah : Mean Sea Level (MSL)

Garis Ungu : Lowest Low Water Level (LLWL)

Pasang tertinggi atau Highest High Water Level (HHWL) merupakan pasang tertinggi dari seluruh periode pasang yang ditarik dari MSL (Garis Merah) ke arah atas. Surut terendah atau Lowest Low Water Level (LLWL) merupakan surut terendah dari seluruh periode surut yang ditarik dari $M S L$ (Garis Merah) ke arah bawah.

c. Fase Bulan berdasarkan $H H W L$ dan $L L W L$ Analisa Data Pasang Surut Perairan Teluk Balikpapan

Fase Bulan dilihat menggunakan aplikasi Tides. Pada tanggal 14 November, fase bulan yang terjadi adalah fase Waning Gibbous 94\% karena terjadi 2 (dua) hari setelah Full Moon (bulan purnama). Pada 
fase ini, bulan terlihat seperti bulan purnama tetapi memiliki bayangan yang sangat sedikit di sisi kiri bulan (Southern Hemisphere) dapat dilihat pada Gambar 9.

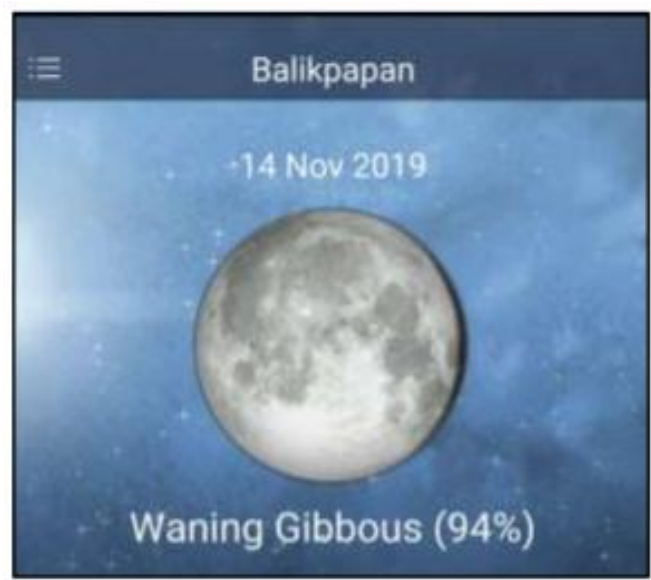

Gambar 9. Fase Bulan Tanggal 14 November 2019 (sumber: aplikasi Tides)

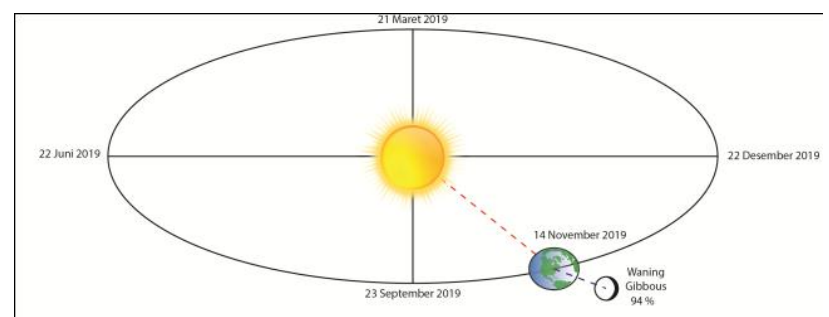

Gambar 10. Posisi Bumi Saat Berevolusi dan Posisi Bulan Saat Fase Waning Gibbous 94\%

Fase bulan yg terjadi pada tanggal 28 November adalah fase Waxing Crescent 5\%, terjadi 1 (satu) hari setelah New Moon (bulan baru). Pada fase ini, bulan hampir terlihat seperti bulan baru tetapi hanya sedikit saja sisi kiri bulan yang tidak terkena bayangan (Southern Hemisphere) yang dapat dilihat pada Gambar 11.

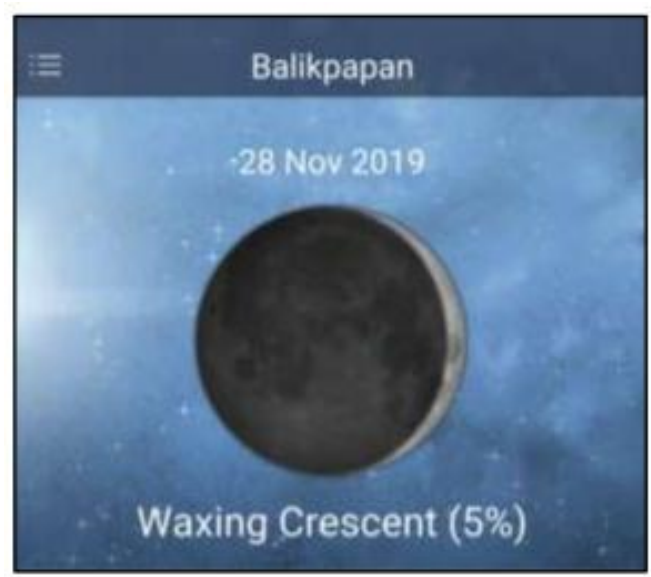

Gambar 11. Fase Bulan Tanggal 28 November 2019 (sumber: aplikasi Tides)

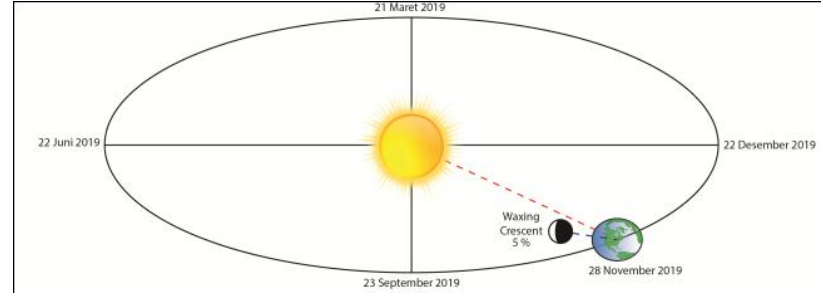

Gambar 12. Posisi Bumi pada Tanggal 28 November 2019 dan Posisi Bulan pada saat Waxing Crescent 5\%

Pada Gambar 10 dan 12, posisi bumi saat berevolusi pada bulan November mendekati matahari sehingga berpengaruh pada nilai amplitudo (A) komponen harmonik pasang surut $M_{2}$ dan $S_{2}$ yang menjadi penentu gaya pembangkit pasang surut yang dominan pada Perairan Teluk Balikpapan. Dapat dilihat juga, kedua fase bulan di tanggal 14 dan 28 terbukti mirror (pembalik) berdasarkan nilai sudut fase $\left(\mathrm{g}^{\circ}\right)$ pada komponen $\mathrm{M}_{2}$ dengan nilai sebesar $197^{\circ}$. Sudut ini berada di kuadran III yang diukur dari $0^{\circ}$ fase bulan menghadap matahari dan azimuth bagian selatan berdasarkan posisi pengamat di Perairan Teluk Balikpapan yang berada di bumi bagian selatan (Southern Hemisphere).

\section{KESIMPULAN}

Kesimpulan dari Kajian Penentuan Karakteristik Pasang Surut di Perairan Teluk Balikpapan adalah sebagai berikut:

1. Pasang surut di Perairan Teluk Balikpapan dipengaruhi oleh gaya pembangkit pasang surut dari matahari $\left(\mathrm{S}_{2}\right)$ dengan nilai amplitudo sebesar 67,99 $\mathrm{cm}$ dan gaya pembangkit pasang surut dari bulan $\left(\mathrm{M}_{2}\right)$ dengan nilai amplitudo sebesar 47,88 cm. Karakteristik pasang surut di Perairan Teluk Balikpapan didominasi oleh gaya pembangkit pasang surut dari matahari $\left(\mathrm{S}_{2}\right)$ karena nilai amplitude dari matahari lebih besar daripada nilai amplitude dari bulan $\left(\mathrm{M}_{2}\right)$ serta posisi bumi saat berevolusi pada bulan November yang mendekati matahari (perihelion).

2. Tipe pasang surut di Perairan Teluk Balikpapan berdasarkan hasil dari perhitungan Formzahl adalah tipe pasang surut campuran, condong ke harian ganda (mixed, prevailling semidiurnal) dengan nilai Formzahl sebesar 0,33.

3. Hasil dari perhitungan Admiralty, didapatkan nilai $M S L$ yang diambil dari komponen harmonik pasang surut $\mathrm{S}_{0}$ yaitu sebesar $1,42 \mathrm{~m}$. Nilai $H H W L$ dihitung dari penjumlahan nilai $S_{0}$ dengan $Z_{0}$, yaitu sebesar 3,33 m. Nilai $L L W L$ dihitung dari pengurangan nilai $\mathrm{S}_{0}$ dengan $\mathrm{Z}_{0}$, yaitu sebesar $-0,31 \mathrm{~m}$.

4. Hasil dari analisa data pasang surut Perairan Teluk Balikpapan, didapatkan nilai $H H W L$ dan $L L W L$ dan fase bulan dilihat menggunakan aplikasi Tides. Fase bulan pada tanggal 14 adalah Waning Gibbous 94\% dengan nilai $L L W L$ sebesar $0,20 \mathrm{~m}$ dan $H H W L$ sebesar 2,90 m. Fase bulan pada tanggal 28 adalah Waxing Crescent 5\% dengan nilai LLWL sebesar 0,20 $\mathrm{m}$ dan $H H W L$ sebesar 2,80 $\mathrm{m}$. 


\section{DAFTAR PUSTAKA}

Anugraha, Rinto. 2012. Mekanika Benda Langit. Yogyakarta. Penerbitan Fakultas MIPA UGM.

Denafiar, Fadhilla Shara. 2017. Pembuatan Program Penentuan Konstanta Harmonik dan Prediksi Data Pasang Surut dengan menggunakan Visual Basic for Applicaion (VBA) MS. Excel. Vol. 6, No. 4:297.

Destarina, Ratih. 2011. Penentuan Datum Vertikal Batas Wilayah Laut.

Doodson, A.T. dan H. D. Warburg. 1941. Admiralty Manual of Tides. London. Her Majesty's Stationery Office.

Fadilah. 2014. Menentukan Tipe Pasang Surut dan Muka Air Rencana Perairan Laut Kabupaten Bengkulu Tengah Menggunakan Metode Admiralty. Vol. 6, No. $4: 2$.

Foreman, M. G. G. 1977. Manual for Tidal Heights Analysis and Prediction. Pacific Marine Science Report, 77-10. Institute of Ocean Sciences. Patricia Bay, Victoria, B.C.

Hicks, Steacy D. 2000. Tide and Current Glosary. Silver Spring MD. National Oceanic and Atmospheric Administration Department of Commerce.

Hidayat, Alvin. 2016. Pemetaan Batimetri dan Sedimen Dasar di Perairan Teluk Balikpapan, Kalimantan Timur. Vol. 5, No. 2:196.

Ichsari, Lintang Fauzia. 2020. Studi Komparasi Hasil Pengolahan Pasang Surut dengan 3 Metode (Admiralty, Least Square dan Fast Fourier Transform) di Pelabuhan Malahayati, Banda Aceh. Vol. 2, No. 2:3 dan 7.

Jamie, 2011. The Phases of The Moon. http://www.synapses.co.uk/astro/moon2.html (diakses pada tanggal 12 Agustus 2020)

Jayanti, Hafni. 2016. Analisis Komponen Pasang Surut Untuk Menentukan Elevasi Dermaga Pelabuhan Kuala Tanjung. Hal 1 dan 3.

Khomsin, Miftakhul Ulum. 2013. Perbandingan Akurasi Prediksi Pasang Surut antara Metode Admiralty dan Metode Least Square. Vol. 9, No. 1:65-66.

Mahatmawati, A. Dewi. 2009. Perbandingan Fluktuasi Muka Air Laut Rerata (MLR) di Perairan Pantai Utara Jawa Timur dengan Perairan Pantai Selatan Jawa Timur. Vol. 2, No. 1:33-34.

Mills, Jerry dan Stephen Gill. 2005. Manual on Hydrography: Water Levels and Flow. Monaco. International Hydrographic Bureau.

Sangkop, Novian. 2015. Analisis Pasang Surut di Pantai Bulo Desa Rerer Kecamatan Kombi, Kabupaten Minahasa dengan Metode Admiralty. Vol. 13, No. 63:62-65.

Siagian, Yanthi Sepriana. 2016. Pemodelan Sebaran Tumpahan Minyak di Perairan Teluk Balikpapan, Kalimantan Timur. Vol. 5, No. 2:271-272.

Sinaga, Afrianto Tua. 2016. Pola Sebaran Sedimen Tersuspensi berdasarkan Model Pola Arus Pasang Surut di Perairan Teluk Balikpapan, Kalimantan Timur. Vol. 2, No. 3:131.
Sulardi, Anom. 2016. Karakteristik Massa Air Bersalinitas Rendah di Perairan Teluk Balikpapan. Hal. 1, 6 dan 15.

Syetiawan, Agung. 2014. Pengembangan Aplikasi Pengolah Komponen Harmonik Pasut Berbasis WEB. Vol. 20, No. 2:95-96.

Poerbandono, Eka Djunarsjah. 2005. Survei Hidrografi. Bandung. PT Refika Aditama. Zafaryab. Muhammad. 2005. Manual on Hydrography: Principles of Hydrographic Surveying. Monaco. International Hydrographic Bureau.

Zakaria, Ahmad. 2015. Model Periodik dan Stokastik Data Pasang Surut JamJaman dari Pelabuhan Panjang. Vol. 1, No. 19:67 dan 69. 